\title{
In Search of Direction After Two Decades of Local Democratic Experiments in China
}

\section{Dong Lisheng}

\section{(2) OpenEdition}

\section{Journals}

Édition électronique

URL : http://journals.openedition.org/chinaperspectives/5274

DOI : 10.4000/chinaperspectives.5274

ISSN : 1996-4617

Éditeur

Centre d'étude français sur la Chine contemporaine

\section{Édition imprimée}

Date de publication : 1 juin 2010

ISSN : 2070-3449

Référence électronique

Dong Lisheng, «In Search of Direction After Two Decades of Local Democratic Experiments in China », China Perspectives [En ligne], 2010/2 | 2010, mis en ligne le 01 juin 2013, consulté le 28 octobre 2019. URL : http://journals.openedition.org/chinaperspectives/5274; DOI : 10.4000/chinaperspectives.5274 
(1)

In Search of Direction

\section{After Two Decades of Local}

Democratic Experiments

in China

DONG LISHENG

Assessment of the implications of experiments with village committee elections since 1987 has changed. In 2006, direct town elections were categorically forbidden, but in 2008 public nomination and public selection were resumed in Guiyang City for district and deputy municipal leaders. The paper explores the rationale behind the decisions and concludes that a strategic choice is pending within the central leadership.

\section{The macro-context}

$D$ rior to the $17^{\text {th }}$ National Congress of the Chinese Communist Party in October 2007, a heated debate was underway among officials and scholars on the general orientation of "reform and opening up," which would reach its $30^{\text {th }}$ anniversary in late 2008. Some argued that the reforms deviated too far from the bottom line tolerable to a communist state; the expanding private sector and shrinking public sector were eroding the socialist state, and more political and economic control needed to be re-imposed by the party-state. The opposing view asserted that only major political reform could alleviate the current tension in society manifested in the gap between rich and poor, between the eastern coastal areas and the hinterland, and between demands for greater development resources and efforts to preserve the deteriorating environment. According to this view, the situation was such that market-oriented reform could not move further without political openness that allowed expression of different interests and recognition of private ownership. The debate became particularly intense when the draft Law on Property Rights, which included clauses on protecting private property, was examined by the National People's Congress. The central leadership put an end to this debate a year or so before the Party Congress. In a rare political move in recent Chinese politics, an article in People's Daily by Premier Wen Jiabao in February 2007 expressed an official line that repeated the Party's stance of 20 years earlier: its work and its focus would remain on economic development, based on the two pillars of keeping a tight lid on political reform while furthering economic reform and opening. ${ }^{(1)}$

The $17^{\text {th }}$ National Party Congress ushered in General Secretary Hu Jintao's second and last five-year term. Expectations were high at home and abroad that he might deliver strong policies now that he has better control of the political centre. Addressing a conference marking the $30^{\text {th }}$ anniversary of the launch of reform and opening on 18 December 2008, Mr. Hu declared "never to take the old closed-off road or to go astray by altering the banner," basically reiterating what Mr. Wen had expressed earlier. What clue can we gain from these messages in judging the fate of political reform? ${ }^{(2)}$

An all-round view of Chinese politics requires shifting the lens from the leadership to society. Despite the official statements made by top leaders, disputes have persisted since the

1. Wen Jiabao, "Guanyu shehuizhuyi chuji jieduan de lishi renwu he woguo duiwai zhengce de jige wenti" (On some issues on the historical tasks in the primary stage of socialism and China's foreign policy), Xinhuanet, 26 February 2007, http://news.xinhuanet.com/politics/2007-02/26/content_5775212.htm, accessed on 14 March 2009.

2. Hu Jintao, "Zai jinian dang de shiyijie sanzhong quanhui zhaokai 30 zhounian dahui shang de Jianghua" (Speech at the meeting to commemorate the 30th anniversary of the convening of the Third Plenum of the 11th Party Central Committee), Xinhuanet, 18 December 2008, http://news.xinhuanet.com/newscenter/2008-12/18/ content_10524481.htm. 
recent Party National Congress among officials and scholars around the "universal values of freedom, equality, human rights, and democracy." Those who claim that these universal values bear the US trademark have expressed the view that the existing Chinese political system demonstrated its advantages during the current international financial crisis and that there is no need to reform it. ${ }^{(3)}$ Wang Changjiang describes such opinions as "the syndrome of insensitivity toward political reform." (4) Zhou Qiren concurs with Yang Xiaokai that the advantages enjoyed by late-developing countries may make politicians ignore the need for political reform, and that when problems reach a crisis level, historical opportunity is lost. ${ }^{(5)}$

According to Wu Jinglian, since early 1980s, China's economic reform has been incremental in nature, i.e., the economic portion under the traditional planning mechanism has been retained while the market mechanism has been applied to developing the private sector and Chinese-foreign joint ventures. The latter has been given much of the credit for China's rapid growth, but has also been blamed for a number of negative effects, which can be summed up as the collusion between power and business, or rent-setting and rentseeking by officials. ${ }^{(6)}$ Is the incremental approach workable for political reform?

China began allowing direct elections at the village level in the late 1980s. Two main views are taken of the consequences of grassroots political reform centred on direct elections. Some scholars believe it will help maintain one-party rule, while others hold that it will bring about radical change or comprehensive political reform. Has the Chinese leadership's assessment of village committee elections changed? If so, what are the reasons?

In policy implementation, Chinese leaders have taken either a bottom-up or top-down approach, or a combination of the two. When village direct elections were introduced in the 1980s, veteran Party leader Peng Zhen envisaged a bottomup development of direct elections to the county or even provincial level. ${ }^{(7)}$ Is this feasible, based on the last two decades of experimentation? What kind of decision is pending in the leadership?

This paper will try to answer these questions by reviewing developments over the past two decades.

\section{A review of developments to date}

Since the introduction of village committee elections nationwide in 1987, China has seen a variety of local initiatives ex- perimenting with residents' political participation and the selection of local officials. In the former case, deliberative democracy has been applied to the budget formulation and approval process of some town governments. ${ }^{(8)}$ Wenling City, Zhejiang Province, took the lead in this area in 2001, bringing local residents and officials together to discuss local affairs, especially government budget formulation and implementation and major public works and services. ${ }^{(9)}$ Many county and city governments have made use of annual public assessments of the performance of government departments or officials. In Nanjing, the capital of Jiangsu Province, municipal government departments are assessed by the public every year, with the leaders of the two lowestrated bureaus removed from office. ${ }^{(10)}$

In the latter case, elections have been expanded to the urban equivalent of village committees, the neighbourhood committees. ${ }^{(1)}$ In 1998, the Sifang District of Qingdao Municipality in Shandong Province organised direct elections for its neighbourhood committees. ${ }^{(12)}$ In the following year, 26 cities throughout the country followed suit in response to a

3. Feng Yuzhang, "Zenyang renshi suowei pushi Jiazhi" (How to understand so-call "universal values"), Renmin Ribao (People's Daily), 10 September 2008, http://www.chinanews.com.cn/gn/news/2008/ 09-10/1377452.shtml.

4. Zhongyang dangxiao jiaoshou: zhenggai mamuzheng wudang wuguo, xu gaodu jingti (Professor of the Central Party School: Vigilance is needed against the syndrome of insensitivity toward political reform as it misleads the Party and state), Nanfengchuang (Southern exposure), 19 January 2009.

5. Zhou Qiren, "Yibu wei wancheng de changquan gaige shi" (A history of unfinished ownership reform), Jingji Guanchabao (Economic observer news), 19 January 2009.

6. Zhang Jianjing, "Shichanghua gaige: Cong nali lai, dao nali qu" (Market-oriented reform: Where it comes from and where it goes), Zhongguo Jingji Shibao (China Economic Times), 3 September 2008.

7. Peng Zhen, "Qunzhong zizhi shi fazhan shehuizhuyi minzhu de zhongyao yi huan" (Mass autonomy is an important link in the development of socialist democracy), Speech at the Chairmanship Meeting of the Sixth NPCSC, 23 November 1987, in Peng Zhen tongzhi guanyu cunmin weiyuanhui, jumin weiyuanhui de zhongyao jianghua (Important speeches of Comrade Peng Zhen on village committees and residents' committees), unpublished compilation, Beijing, Minzhengbu jiceng zhengquan jianshesi, 1990, p. 25.

8. He Baogang and Wang Chunguang, "Deliberative Democracy in Rural China: A Case Study," Sociological Studies, DOI:CNKI:ISSN:1002-5936.0.2007-03-004; He Baogang, The Search for Deliberative Democracy in China, New York, Palgrave Macmillan, 2006.

9. Jia Xijin, "Zhongguo canyushi minzhu de xin fazhan-Zhejiang Wenling minzhu kentanhui chuanxin moshi fenxi" (The new development in the participatory democracy in china-an analysis of the innovative model of consultative meetings in Wenling, Zhejiang), http://www.chinaelections.org/NewsInfo.asp?NewsID=111914, accessed on 26 January 2009.

10. "Li Yuanchao tan mowei taotai, dang ganbu jiu gai you yali"(Li Yuanchao talks about the method of laying off the person graded last in the performance evaluation and putting Party executives under pressure),China News Service, 30 March 2002, http://news.china.com/zh_cn/domestic/945/20020330/10234423.html.

11. I coordinated projects for training electoral staff and monitors of neighbourhood committee elections in the Guangxi Zhuang Autonomous Region and Fujian Province between 1998 and 2004

12. Ministry of Civil Affairs, "Chuanjian quanguo wenming chengshi dui shequ jianshe de qishi" (Enlightened promotion of cities with an advanced culture of community building), 9 November 2007 
directive by the Ministry of Civil Affairs. But in some cities, such as Shanghai and Nanjing, residents failed to participate enthusiastically. The ice was broken after two towns in Nanning Municipality, Guangxi Autonomous Region, successfully organised direct elections in all of the eight neighbourhood committees under their jurisdiction in July 2001. ${ }^{(1)}$ By 2002, such elections expanded from large cities to mediumsized and small cities, and from sporadic experiment to collective action in urban districts or cities.

Direct elections in village autonomous organisations have spilled over to the election of village Party branches with the invention of a two-ballot system in Hequ County, Shanxi Province. The new method involves ordinary villagers first casting votes in opinion polls regarding the candidates. Then Party members elect the Party branch on the basis of the list resulting from the popular vote. ${ }^{(14)}$

Furthermore, direct elections have been upgraded from nongovernmental village autonomous organisations to the lowest level of township government. Sichuan Province took the lead in such experiments. At the end of 1998, Nancheng Township in Qingshen County and Buyun Township in the Central District of Suining City organised direct elections of government leaders at almost the same time. ${ }^{(15)}$

Various forms of indirect elections have been used to select Party and government leaders up to the prefectural level. In 1999, Dapeng Town in Shenzhen Municipality organised three consecutive rounds of polls involving three groups of local elites to select the head of government. This more restrictive solicitation of popular opinion was soon expanded by Zuoli Town in Shanxi Province, where all eligible voters cast a vote of confidence followed by a vote of the deputies of the Town People's Congress. ${ }^{(16)}$ The so-called "two ballot system" is the extent of open elections at the lowest level of government; ${ }^{(17)}$ an earlier Buyun Township election that took the popular vote as final was ruled "unconstitutional" by the central government. ${ }^{(18)}$ The "public nomination and public selection" method was used to select both the Party secretary and government leader in Yangji Town, Hubei Province, in 2002. ${ }^{(19)}$ The various forms of experiments are summed up in List 1.

Experiments with competitive elections have also been carried out in the selection of deputies to People's Congresses at the township and county levels. Its significance lies in the fact that although the law required deputies at these two levels to be directly elected as early as 1982, in most cases the elections have been organised perfunctorily, with a low level of competition or none at all. ${ }^{(20)}$ Experiments in this vein have been conducted in the last three years or so against a

\section{List 1. A Summary of Different Methods for Selecting Township Leaders}

- Direct election by all voters (Buyun Township, Suining City, Sichuan Province).

- "Three-ballot system" (Dapeng Town, Shenzhen Municipality, Guangdong Province): voters nominate candidates; elites select final candidates for the People's Congress (PC); PC deputies elect the leader.

- "Two-ballot system" (Zuoli Town, Linyi County, Shanxi Province), also used for the selection of the Party secretary \& PC Chairman: Voters cast vote of confidence; the Party committee nominates candidates; the Party congress or People's Congress elects leaders.

- "Public nomination, public selection" (Nanbu County \& Suining City, Sichuan Province): Top six in written exams attend oral exams administered by 100 -odd elites. The subsequent procedure is same as the last step of option 3.

- The PC deputies (rather than the county Party committee) directly nominate candidates (Mianyang City, Sichuan Province).

- "Two nominations plus election" (Yangji Town, Jingshan County, Hubei Province) Similar to the method used by Dapeng Town, but the second nomination is made by the Villagers' Representative Assembly.

14. Dong Jiangai, "Liangpiaozhi, liangtui yixuan and yijiantiao de chuanxinxing" (0n the innovations of the two-ballot system, two rounds of nominations and election and concurrencies), Socialism Studies, No. 6, 2007

15. Xin Ran, "Xiangzhen zhixuan, zhenzai shiyan de nongcun minzhu xingsh" (Direct township election: A form of rural democracy under experiment), Dangdai Shaanxi (Contemporary Shaanxi), vol. 6, 2005. Yang Min, "Sichuan jiceng minzhu tansuo 10 nian: 98 nian diyici zhixuan xiangzhang" (Ten years of grassroots democratic exploration in Sichuan province: The first direct election of the township government head in 1998), Juece (Policy Making), 25 March 2008.

16. Du Ganjian, "Xiangzhenzhang xuanju zhidu gaige yanjiu" (Research on the reform of direct elections of township government leaders), Centre for People's Congress and Foreign Legislature Study, 20 January 2002, http://www.e-CCPs.org/newsinfo.asp? Newsid $=7409$.

17. In Zuolin Town, the "two ballot system" was used for the election of the township Party committee and government leaders. The first ballot was cast by ordinary voters and the second by the Township People's Congress deputies for the election of the government leader, or by Party members for the election of the Party Secretary. In Hequ County, the "two ballot system" was applied to the election of the village Party branch secretary, with villagers taking part in the primary elections and Party members endorsing the results of the primary.

18. Zha Qingjiu, "Minzhu bu yunxu chaoyue falu" (Democracy is not permitted to exceed the limits of the law), Fazhi ribao (Legal affairs daily), 19 January 1999.

19. Long Gong, Zhang Shihong and Zhou Zhibin, "Hubeisheng shouwei 'haitui zhixuan' xiangzhen dangwei shuji changsheng" (Hubei Province has its first township Party secretary by the method of "sea nomination and direct election"), 7 January 2003, www.people.com.cn.

20. E E, "Wo suo canjia de renda daibiao zhixuan" (The direct election of deputies to the people's congress in which I participated), China Elections \& Governance, http://www.chinaelections.org/NewsInfo.asp?NewsID =101592, 18 January 2007. 
background of discouragement through formal directives or circulars from mid-level authorities, but support from individual officials at higher levels.

In summation, local democratic experiments represented by village self-government reached high tide at the turn of the century, as demonstrated by the developments described above. Here it is necessary to respond to possible challenges to my applying the term "democracy" in the context of the local experiments discussed in this paper. My response is twofold: first, what has been carried out in China to date is of course not Western-style democratisation, even though it is worth emphasizing a point made by G. Schubert on this issue:

(...) much depends on the people's perception of what is democratic and what is not. In that sense, there might be some justification for the Communist Party to speak of such a thing, if only it has the support of the people (...). ${ }^{(21)}$

Secondly, I find it necessary to differentiate between what has been permitted to date (or the current state of the experiment) and what the reformers desire. The veteran leader Peng Zhen envisaged that implementation of direct elections in the villages would have a bottom-up chain effect on higher levels of government. A review of Zhao Ziyang's views expressed in office and in retirement may also provide a convincing footnote. Few would have commented that his political reform programme as announced in 1987 meant installing a multi-party system at all levels of government. We should not equate what has been done with what is desired. Likewise, the nature of the experiment should not be judged by its success or failure. Both the Chinese and Western governments have acknowledged that the 1989 student movement was pro-democracy in the Western sense, although it was suppressed. Referring to the previous statement that local democratic experiments reached a high tide, the following two points are particularly noteworthy:

First, the Organic Law of the Village Committees was revised and enacted by the National People's Congress in 1998 as a formal law after 11 years as a "law for trial implementation." The new law incorporates the experience of the nationwide experiments in the previous decade by endorsing the so-call "sea election" (election without candidates decided by primary elections) used for the first time in Lishu County, Jilin Province, as well as enlarging the scope of election and guaranteeing, to a greater extent, the voters' free expression of will with the availability of a private booth for writing ballots. ${ }^{(22)}$
Second, all provinces, municipalities directly administered by the Central Government, and autonomous regions have organized direct village elections since the adoption of the new law. Prior to 2001, Guangdong and Yunnan provinces had dispatch offices of the township government located in the villages. These offices were staffed by appointees of the township government, and therefore no direct elections were required. The nature of the law for trial implementation meant that provinces could decide not to organise village committee elections.

All these experiments share a common characteristic: they are government promoted or guided. Under the government organisation, local residents or cadres go to the polls and in the process receive training in democracy. This kind of mobilised democracy is meaningful as a first step of democratisation, but also brings limitations leading to later difficulties or stagnation. Since 1998, tensions have become apparent between village committees and village Party branches, and between village and township governments, with the implementation of the new law. These tensions impede the further development of village self-government. Proposed solutions to smooth out the two sets of relationships are confined to guaranteeing the Party's leadership and control of the government. More specifically, the response to the first tension was the "two ballot system" adopted by Linyi County, Shanxi Province, in which one official serves concurrently as chairman of the village committee and secretary of the village Party branch. They still operate under the dual confines or within the limits of mobilised democracy, and their effect has been modest as a result. The response to the second type of tension has been increasing the transparency of the township government administration. In reality, however, most township governments find all kinds of ways to limit openness. The nature of village self-government, i.e., domination by the government, means that the relationship between the village and township governments takes precedence, and the institutional deficiencies of mobilised democracy does not offer any effective way out of this. The frequency and wide range of disputes over village elections and the interference of township governments in village self-government highlight these deficiencies.

It was against this background that the $16^{\text {th }}$ National Party Congress in 2002 adopted the approach of "using intra-party

21. Gunter Schubert, "Democracy Under One-Party Rule? A Fresh Look at Direct Village and Township Elections in the PRC," China Perspectives, no. 46, March-April 2003.

22. Xinhua Daily Telegraph, "Lishu: Haixuan danshengdi' minzhulu geng kuan" (Lishu: The place where the "sea elections" were born enjoys brighter prospect for democracy), 14 September 2009. 
democracy to promote the people's democracy." (23) Innovations in intra-party democracy include competitive elections of deputies to town and county Party Congresses; annual sessions of Party Congresses instead of once every five years; and making decisions on important matters, especially the official appointments, through the full Party committee instead of only through its standing committee. The value and implications of these measures in China's democratic development will be discussed later.

In 2006, direct town elections were categorically forbidden. In 2008, public nominations and public selection were resumed in Guiyang City for district and deputy municipal leaders. ${ }^{(24)}$ The difference between direct elections and public nomination and selection lies in the former being open to all eligible voters, and the latter extended only to local elites.

Of all these types of experiments, direct village and township elections are the most significant new steps in democratisation because they present real choices to voters, and candidates compete with their own platforms or promises to voters. This will also be be discussed at greater length later in this paper.

\section{The changing assessment of implications and experiments}

Around 1980, when the first few village committees were voluntarily set up by farmers in the Guangxi Zhuang Autonomous Region, they soon won the recognition of the party-state, as they filled a management vacuum that had developed in the rural areas following the collapse of the commune system. The central leadership reached a consensus on the institutionalisation of village self-government, and indicated its approval of the role of village committees in reorganising farmers by quickly enshrining their official status in the Constitution in 1982. The consensus was built on a balance of pragmatism and ideology. Village self-government was found to be as effective in organising rural society as a government dispatch office, but with lower administrative and fiscal costs. Ideologically, village self-government was a continuation of the CCP's mass line in that, on the one hand, it is an invention of farmers that should be respected by the Party, and on the other hand, the institutionalisation and function of the new grassroots organisation embody the mass line, or village self-government is institutionalised mass line: it serves to increase the farmers' identification with the party-state by partially empowering them. This consensus explains how village self-government could overcome obstacles at the early stage and become an officially endorsed form of organisation at the grassroots level in the rural areas. ${ }^{(25)}$
Ever since village self-government was instituted, two different assessments of the movement have persisted. Its proponents wanted to use it to empower rural residents and initiate the promotion of democracy in China, with a view to upgrading gradually to the county and even provincial level. These advocates have become more confident of such a prospect with recent developments resulting from the implementation of direct township elections.

Opponents, on the other hand, have no faith in the proper exercise of democratic rights by rural residents, whom they regard as lacking in democratic concepts and skills, and they allege that village elections are prone to domination by clans or control by money politics. The Party apparatus is loath to relinquish the party-state's control over the villages, and anticipates that direct elections will result in village committees composed of non-Party members. Local government departments, especially at the township level, fear loss of control over villages with the conversion of the relationship between the township and the village from "leadership" to "guidance." They see inevitable conflict between the right of selfgovernance and government administrative power, and fear that deterioration of village self-governance will become a source of unrest in the rural areas.

For these reasons, central leaders led by then-NPC Chairman Peng Zhen and the implementing agency, the Ministry of Civil Affairs, were obliged to make a tactical retreat: the force of the proposed Organic Law on Village Committees was reduced by turning it into a law for trial implementation; it would first be implemented in some experimental areas to gain experience, but the priority was placed on obtaining the support of the local Party and government for implementation rather than on achieving a certain standard of democratic election, management, decision-making, and supervision.

After a few years of experiments after 1988, the Ministry of Civil Affairs identified direct elections as the key to the institutionalisation of village self-government. The work focus was placed on designing relatively free and fair electoral procedures that would allow "capable persons" to serve in the

23. Hu Jintao, "Report to the Seventeenth National Congress of the Communist Party of China on 15 0ct. 2007," Xinhua, 24 0ctober 2007, http://news.xinhuanet.com/english/2007-10/24/content_6938749.htm, accessed 7 November 2008.

24. Han Xue, "Guiyang dangzheng ganbu renmian gaige: Gongtui gongxuan, ganbu jinggang" (The reform of the appointment and removal of party and government cadres: public nomination and public selection, cadres compete for positions), www.news.cn, http://news.xinhuanet.com/politics/2008-12/15/content_10508639.htm, accessed 12 February 2009.

25. Li Fan, Grassroots Democracy 2004, Beijing, Intellectuals Property Publishing House 2005 
village committees. They were expected to help consolidate grassroots organisations, maintain local social order, and promote local economic development. To this end, the Ministry formed a united front with local government. Village selfgovernment to some extent improved relations between the party-state and farmers and alleviated conflicts between officials and villagers. This fact brought about a temporary partnership between the Ministry and the Party departments.

However, with the rigorous promotion of direct elections in village committees over the course of a few years, doubts over their value emerged. Given that Party branches form the "leadership core" in the villages, no matter how competitive elections were and how competent and accountable the elected cadres were, the democratic value of such experiments was limited. However, the two-ballot system that opened positions in the Party branches to the poll of ordinary villagers improved the quality of village democracy to some extent. Up to this point, it seemed that village self-government was still viewed positively by the central leadership. It is notable that in 1998, former President Jiang Zemin praised it as "the third invention" of Chinese farmers, following the introduction of the household contract responsibility system and the development of rural enterprises. ${ }^{(26)}$

The end of 1998 saw the first breakthrough in upgrading direct elections to the township level with an experiment in Suining County, Sichuan Province. The immediate official reaction of the central leaders was negative, but elections less competitive than in Buyun Township were nevertheless organised in several provinces. Later, the emphasis of experiments was placed on the opinion poll of candidates for secretary of the township Party committees. Following the decision of the NPC in October 2004 on extending the term of office of the town (township) government from three years to five, elections for deputies to the People's Congresses at the county and township levels were scheduled for between July 2006 and December 2007. ${ }^{(27)}$ This should have provided opportunities for further experiments, but to the disappointment of some reformers, Sheng Huaren, Vice-Chairman of the NPC Standing Committee, reiterated in August 2006 that direct elections of township government leaders were illegal and warned that evil foreigners were using the tool of human rights and democracy against China. ${ }^{(28)}$ As noted previously, no more experiments were carried out until 2008.

The current setback or stagnation is in fact related to the institutional limitations of mobilised democracy. These built-in confines can be summed up as follows: (1) the contradiction between the varied goals of mobilised democracy; (2) the conflict between its means and ends; (3) conflicts within the power structure of the party-state; and (4) the conflict between policies and laws.

The party-state aims to give local residents some political freedom in the form of participation in the management of local affairs while keeping ultimate control of grassroots autonomous organisations. In this context, the village committees and the neighbourhood committees carry the dual characteristics of administrative and autonomous organisations. On the one hand, committee members are agents of the local government, responsible for fulfilling the tasks of the state. On the other hand, they are leaders of the local community, responsible for handling local affairs and conveying residents' demands and opinions to the government. Their dual role originates from different and sometimes conflicting sources, and draws different expectations from the government and local residents. When the interests of the local government and residents are similar, their days are easy, but when the two conflict, committee members will be blamed by either the government or residents. The tradition of centralisation has allowed the state to extend its reach to the grassroots, resulting in serious interference in local autonomy. In the rural areas, the township government often meddles in village affairs, even unlawfully removing elected village committee members from office. Through clever manipulation it can effectively control a village committee via the village Party branch.

The reason the party-state resorted to mobilised democracy was to adjust the mode of local management. But the use of democratic election, management, decision-making, and supervision allows the new governance model to operate according to its own rules, which are often unacceptable to the local government. For example, the government devoted much effort to improving electoral rules and procedures at the early stage of direct elections, when villagers doubted that they would actually be allowed to hold free and fair elections. Since then, villagers have often used these improved regulations to resist interference by the local government. The local Party organisation departments used to appoint vil-

26. Renmin Ribao (People's Daily), 25 September 1998, p.1.

27. NPC, "Quanguo xian xiang liangji renda huanjie xuanju 2006 nian 7 yue 1 ri zhi 2007 nian 12 yue 31 ri juxing" (Nationwide elections during the term change of the people's congresses at the two levels of county and township scheduled for 1 July 2006 and 31 December 2007) http://npc.people.com.cn/GB/28320/62275/, accessed on 14 March 2007.

28. Sheng Huaren, "Xian xiang renda huanjie mianlin xin wenti, xu jianchi sange yuanze" (The term change of the county and township people's congresses faces new problems and three major principles must be adhered to), in Seeking Truth, available at the website of the NPC on 30 August 2006, http://npc.people.com.cn/GB/14554/ 4758934.html, accessed on 14 March 2007. 
lage leaders under the principle of "Party control of cadres." With competitive elections placing more non-Party members in village committees, the Party organisation departments have become concerned and have exerted pressure on the government departments responsible for village self-government. The central and mid-level government on the one side, and the township government on the other, sometimes clash over the implementation of grassroots autonomy. According to the Organic Law of the Village Committees, the township government can only guide rather than lead the work of the village autonomous organisation; but in fact, the township government cannot operate effectively without the support of village cadres. Heavy-handedness by township officials tends to strain township governments' relations with village committees, and wronged village cadres often win the sympathy of central and mid-level officials. After the formation of a political alliance among local officials, elites (including village cadres), and economic enterprises, a new tripartite power pattern has emerged in recent years between the central government, local government, and farmers. The local government tends to use all means to protect local interests and expects the central government's support. Normally the central government ignores the improper behaviour of local governments, so long as they maintain local stability. As a result, farmers' interests are often sacrificed.

The CCP depends on policy as a tool for exercising its leadership. This was not a problem at the early stage of mobilised democracy, but its stable development cannot proceed without laws. The development of democracy will inevitably contradict the interests of local Party departments; hence there must be laws, and the laws must be obeyed. If the rule of law is to be respected, policies must sometimes give way. Several debates have occurred in the process of mobilised democracy. On the basis of the Organic Law of the Village Committees, some people argue that the committee is the highest authority in the village, as it is elected by all eligible voters, and the Party branch should follow its leadership instead of standing above it, because the Party branch is not endorsed by the villagers. This interpretation naturally has many opponents. The verdict of the CCP Central Committee is that the Party must lead the village committees. In the current policy environment, the relevant existing laws sometimes encounter enforcement difficulties, and not all prospective laws required for democratic development are likely to be enacted. As sound laws pose difficulties to any attempts to control elections, it is understandable that in the important field of democratic development, a vacuum remains in the realm of law.

\section{An exploration of the rationale behind the decision to mobilize democracy}

Direct village and township elections have many layers of political implications. While they have had a direct impact on the lowest levels of government, they have also had longterm and strategic influence on China's meso- and macropolitics. Nobody can predict the political outcome of direct elections, either in theoretical or practical terms. This results in differing opinions among central leaders and vacillation over the development of grassroots democracy.

More specifically, direct village elections have a number of political implications for local governance: (1) their impact on the status of village Party branches (strengthening or weakening); (2) the possibility that village elections will produce cadres more inclined to listen to the opinions of villagers and safeguard their interests; (3) the possibility that village elections could weaken the township government's political control over village institutions; (4) the possibility that village elections could make state policies difficult to implement in the countryside.

From the macro-political perspective, the fundamental question is whether village elections are conducive to enhancing the legitimacy of the Chinese Communist Party. A related concern is whether implementation of direct elections in the villages will start a bottom-up chain effect that will reach the higher levels of government, as Party veteran Peng Zhen envisaged.

From the outset, grassroots democracy has been considered compatible with strong control by the party-state, and elections were designed to increase mass support for the Party. With this understanding, allowance was made for the gradual upgrading of elections as a route to China's democratisation. However, the 2000 Taiwan elections saw the end of the longterm rule of the Kuomintang, while a series of "colour revolutions" in Eastern Europe and Central Asia resulted in proWestern governments coming to power. It was against this background that Chinese leaders increased their vigilance against the so-called peaceful evolution strategy of the West. In a notable related move, the government also tightened control over NGOs. Then came the NPC decision forbidding further experiments with direct township elections, under the assumption that direct elections could threaten the Party's rule rather than consolidate it as previously believed. If this analysis holds water, the decision is still in line with the Party's overriding concern with strengthening its governing capability. It is worth here reviewing the background and original goal of the party-state's decision to mobilise democracy. In 1978, when reform and opening was launched, the Chinese lead- 
ership abandoned collectivism in the economic sphere for a policy that permitted both economic growth and inequality. Meanwhile, in the political sphere, the strategy of administration absorbing politics was meant to satisfy demands for political participation on the part of political, economic, and intellectual elites for the sake of the regime's stability. In addition, the traditional model of mobilised political participation was still used. Some central leaders wanted to continue political socialisation of the masses through a kind of institutionalised mass line, i.e., grassroots autonomy as a platform for local residents' political participation. Although this policy was compromised by the economic development model of local authorities, economic deprivation of farmers in the modernisation process, and non-democratic culture and ideas, interaction between central and local leaders produced a consensus on "electing capable persons," and mobilised democracy gained traction.

Since mobilised democracy was launched by the party-state, it could be applied nationwide. However, its origins with the central authorities gave it an innate ideological conservatism, which explains why the development of mobilised democracy ground to a halt once it transcended originally envisaged boundaries. Local governments, on the other hand, have demonstrated more varied attitudes. Their initial opposition and later support both reflect consideration of their own interests, with much less regard for ideology. They have been willing to promote mobilised democracy if they deem it effective in dealing with local problems.

Both the initial design of the central authorities and local governments' acceptance demonstrate an adjustment of governing mode in light of economic and social change. On the side of the party-state, mobilised democracy is a form of grassroots autonomy and therefore an adjustment of the relationship between the state and society. Both village selfgovernment and urban community self-government represent an effort by the party-state to transform grassroots organisations from administrative bodies to autonomous bodies in the context of the state's adjustment of society's governing mode. The nature of both kinds of self-government is an institutional arrangement based on the state's delegation of power to society rather than an institutional arrangement based on the transfer of rights from local residents to the autonomous organisation. Under this arrangement, the government concedes to society a very limited autonomous space, namely, residents' limited right of participation through tightly controlled grassroots autonomous organisations. Local autonomous organisations take implementation of party-state policies as their primary mission while enjoying limited au- thority in the handling of community affairs. The party-state grants limited rights of election and participation in the management of local affairs in hopes of producing "capable persons" who obey the orders of the higher authorities.

Under China's unified party-government political system, the central authorities have emphasised the consolidation of local Party organisations and their leadership role in implementing mobilised democracy. In fact, both village self-government and urban community self-government are promoted as contributing to the building up of local Party organisations. In elections for grassroots autonomous organisations, the party-state has always put a priority on ensuring that Party members are elected. In short, mobilised democracy has little space for development.

While considering what the party-state holds back, it is also necessary to note what has been proposed and implemented. Intra-party democracy and the people-first policy should be discussed against this background.

The CCP has declared intra-party democracy to be vital to its survival, and it has been an important topic among scholars since it was officially put forward at the $16^{\text {th }}$ National Party Congress in 2002. The basic concept and approach of "expanding intra-Party democracy to develop people's democracy" were reiterated during the Fourth Plenum of the $17^{\text {th }}$ CCP Central Committee in September 2009. ${ }^{(29)}$

The importance attached to intra-party democracy is in fact a response or gesture toward ever-louder calls for democracy in society. The increasing social space since reform and opening has created pressure from outside the system, and democratic development in society has posed demands for reform within it. In an era in which democracy is developing in society, if the Party maintains authoritarian rule, it may be torn by internal dissension and discord and shunned by the public. Facing societal pressure, the Party was obliged to place political reform on its agenda. A practical challenge has been the search for safe means for reform. Compared with delegating some power to society or allowing societal democracy, intraparty democracy is safer, as delegating authority to lowerlevel Party organisations and allowing Party members to enjoy greater freedom and participation do not threaten the Party's ultimate control. Hence, intra-party democracy became a rational choice for the Party in promoting democracy. But it is a passive choice.

In general, most scholars within the establishment hold positive views of the relationship between the intra-party democ-

29. Xinhua News Agency, "ССР to expand intra-Party democracy: Communiqué," 18 September 2009 
racy and democracy for the nation as a whole. According to Wang Guixiu, making the development of intra-party democracy the breakthrough point of political reform is the best option, as it is substantive, affects other sectors, and is lowrisk. ${ }^{(30)} \mathrm{Xu}$ Yaotong holds that under conditions in which democracy is lacking in the Party and society, developing intra-party democracy to promote democracy among the people is feasible and helps avoid risks and faults. ${ }^{(31)}$ Scholars disagree on how to implement intra-party democracy, however. Some are for a top-down approach, while others believe that a bottom-up approach is preferable.

Local experiments in promoting intra-party democracy have produced some positive effects, mainly reflected in the annual sessions of local Party congresses, the direct election of Party Secretaries, and checks and balances between Party departments, as noted previously. In general, however, they have not surpassed similar experiments involving township government and village organisations. At the same time, the limitations placed on the experiments have brought about new problems. Distortion in the implementation process, as reflected in the dominance of leaders over participation by ordinary Party members or local residents and their decisions, render intra-party democracy largely symbolic. The reputation of such experiments raises little hope among the public, as a result of which they serve neither to effectively enhance the legitimacy of the Party's rule nor to improve local governance. The gist of the issue is the reluctance of power-holders to share power. The situation raises doubts about the strategy itself. Intra-party democracy is intended to facilitate people's democracy, but the fact is that this concept was preceded by democratic experiments in the direct election of village committees. Before intra-party democracy can serve as a role model for societal democracy, it must catch up with the latter in both scope and quality. There has been no sign of this happening so far. It is therefore valid to ask whether it is merely a tactic or excuse to hold back the momentum for direct election of township government leaders.

Difficulties in promoting both local and intra-party democracy may have prompted Chinese leaders to consider an alternative, and it may not be cynical to analyze the peoplefirst policy in this context. In his government report delivered to the annual session of the NPC in March 2007, Premier Wen Jiabao put forward specific programs for improving the people's livelihood, such as provision of health care and social security packages to all eligible citizens, and efforts to ensure that all students admitted to colleges and universities are able to attend through the provision of scholarships to the eligible and the waiving of tuition fees for all students of teachers' universities run by the Ministry of Education. ${ }^{(32)}$ These can be regarded as concrete measures for implementing the Building the New Countryside Program as formulated under the concepts of scientific development and promotion of a harmonious society advanced by Premier Wen and President $\mathrm{Hu}$ Jintao. The measures indicate a shift in the government's focus from single-minded pursuit of GDP to provision of public goods and services.

The active promotion of these people-first policies contrasts with discouragement of the experiment on direct elections. Does this indicate a reconsideration of the emphasis on local governance and a new understanding of the route for China's political development?

It seems that the Party now prefers people-first policies based on maintaining rapid economic growth. As Premier Wen recently stressed, while extending democracy, improving the legal system, and continuously pushing forward political structural reform, attention is currently focused on spurring economic development, safeguarding the rights and interests of citizens, combating corruption, improving governmental trustworthiness and effectiveness, and promoting social harmony. ${ }^{(33)}$ In order to improve the provision of public goods and services, efforts are being made to strengthening central power, with a notable recent trend toward reviving vertical control. Of course, to the Party all means of prolonging its grip on power are acceptable, whether its legitimacy is based on active popular support via elections or passive consent resulting from the Party's ability to continue delivering benefits.

\section{A strategic choice pending in the central leadership}

The experiments to date have proven that China should and can introduce direct elections to the lower levels of government, beginning with the township level. The top leadership should make a political decision to that end, rather than an ill-advised acquiescence by central leaders individually or collectively to further experiments with the models created

30. Wang Guixiu, "The breakthrough point of political reform: Developing intra-party democracy," Beijing Observation, vol. 2, 2003, p. 11.

31. Xu Yaotong, "On intra-party democracy, “ www.people.com.cn, 15 November 2006.

32. Xinhua News Agency, "Shijie quanguo renda wuci huiyi Kaimuhui Wen Jiabao zuo zhengfu gongzuo baogao wenzi shilu" (The proceedings of the opening session of the 5 th Annual Meeting of the 10th NPC on Premier Wen's Government Work Report), http://www.xinhuanet.com/zhibo/20070305/wz.htm, accessed on 14 February 2009.

33. Wen Jiabao, "Guanyu shehuizhuyi chuji jieduan de lishi renwu he woguo duiwai zhengce de jige wenti"(0n some issues on the historical tasks in the primary stage of socialism and China's foreign policy), Xinhua Net, 26 February 2007, http://news.xinhuanet.com/ politics/2007-02/26/content_5775212.htm, accessed on 12 February 2009. 
in the past two decades. One reason is, as a prominent local reformer has concluded, that bottom-up reforms are too costly and sub-optimal. Luo Chongmin has gained fame nationwide as an official who has promoted comprehensive reforms in many fields: When he was Party Secretary of Honghe Prefecture, Yunnan Province, Luo carried out large-scale experiments involving direct township elections (planned for the whole prefecture and actually organised in one county), merging the rural and urban residential registration systems, and conversion of hospital and media institutions into limited liability companies. He comments that all such reform should start at the top. ${ }^{(34)}$

The other reason is that the various forms of public nomination and selection are too procedurally complicated. Frequent elections for various positions are burdensome in terms of expenditure of human and material resources, and could lead to premature apathy toward elections among ordinary voters.

The areas most active in promoting local democracy organise too many different elections, including for village committee, village Party branch, township government leader, township Party secretary and Party committee members, and deputies to the county and township People's Congresses. In addition, electoral rules and procedures typically require primaries for each category of election. The constant stream of elections can easily produce an over-politicised environment that becomes a burden on citizens and that is less than conducive to fostering a sound electoral and political culture.

I participated in an experiment to combine some categories of elections under a project entitled "Support Township Competitive Elections" in Ya'an Municipality, Sichuan Province from 2004 to 2006. ${ }^{(35)}$ Four townships organised direct elections of Party and government leaders as well as deputies to the township People's Congress on the same day in April 2006. The experiment was successful in combining the different elections and improving competitiveness, but it could not avoid complicated procedures under the applicable Party rules and local electoral laws and regulations.

A review of the process revealed a conspicuous drawback: procedures for competitive elections of township Party and government leaders are too complicated, as they have to abide by the applicable Chinese electoral rules while trying to adopt basic electoral procedures used elsewhere in the world.

The prevailing Chinese procedure for choosing candidates for township Party and government leaders includes the following steps:

a) the county Party organisation department carries out an opinion poll;

b) relevant departments or leaders nominate candidates; c) a list of primary candidates is proposed by the party organisation department after the survey;

d) a decision is reached by the county Party standing committee and full committee;

e) candidates are officially nominated by the township Party committee or $\mathrm{PC}$ presidium;

f) election procedures are initiated as prescribed by law. In comparison, the procedure for public nomination of township Party and government leaders is more complicated:

a) set up a leading group for public nomination;

b) publicity and training activities;

c) registration of candidates;

d) screening of registered candidates by the county leading group;

e) screening of registered candidates by the county Party committee;

f) list of registered candidates published;

g) campaigning by registered candidates;

h) vote by all eligible voters;

i) announcement of election results;

j) endorsement of the election results by the county Party committee;

k) list of official candidates published;

l) initiation of the election procedure as prescribed by law. (This means the People's Congress deputies vote for, and the People's Congress presidium appoints, the township government leaders.)

From the above, it is clear that the procedures for public nominations include elements and steps of both the traditional method of deciding candidates and the open and competitive election procedures employed internationally. One of the reservations expressed regarding the immediate introduction of competitive elections at the township level is that organising elections is too costly. The adoption of direct elections would reduce the cost by simplifying the procedures. It would also remove the possibility of different outcomes between the popular vote and the vote by People's Congress deputies, and therefore requires a political decision at the top. It would be beneficial to both the Party and the people if decisive competitive elections were put into practice before the introduction of direct elections. Decisive competitive elections mean

34. Pan Xiaoling, "Qiguan Luo Chongmin" (An extraordinary official, Luo Chongmin); "Zixiaershang gai shi gao chengben de gaige" (Bottom-up reform is high-cost), Southern Weekend, 15 January 2009, pp. 1-2.

35. Stig Thoergensen, Joergen Elklit, and Dong Lisheng, "Consultative elections of Chinese township leaders - report on a recent experiment in Ya'an, Sichuan," China Information, vol. XXII (1), 2008, pp. 67-89. 
that the results of the popular vote should be binding or final, and the township People's Congress should normally endorse the results of the popular vote - otherwise the electorate can recall the $\mathrm{PC}$ deputies. Candidates should gain qualifications through a public servant training system once the current multiple screenings are abolished. This will ensure the implementation of Party policy and state law at the lower levels of government after the introduction of direct elections.

\section{Concluding remarks}

Efforts to denigrate universal values have resulted in powerful forces against democratisation of Chinese politics. But as the $\mathrm{Hu}-W e n$ leadership recently reiterated, the move towards rule of law and democracy is endorsed in the Party's political platform, so the general direction is likely to be maintained. In the face of vocal opposition, however, local reformers may hesitate to consider further experiments. A greater challenge now faces the central leadership: a race between corruption and reform has brought about another race between reform and revolution. ${ }^{\left({ }^{36)}\right.}$ It would seem that the more realistic option is to design democratic reform that will make local officials accountable to the public without immediately undermining central control. The incremental approach to political reform has achieved dubious results thus far. Experiments with increasing competition in township elections show that maintaining the existing cadre appointment procedures introduces too many complications and waters down the reform aspects. Indeed, unlike in the economic sphere, it is unthinkable to create a new polity alongside the existing one. With only one government leadership at any level, incremental reform can involve no more than instilling greater competition into selection procedures rather than leaving the existing polity intact while creating a new one for experiment. The effectiveness of the various existing experiments is questionable, however, given that cumbersome procedures test voters' endurance.

It may be too early to claim that new consideration has been given to the bottom-up strategy of democratisation. Even if that proves to be the case, it remains consistent with China's basic approach to reform as set by Deng Xiaoping, which focuses on implementing market-oriented economic reform while keeping a lid on political reform. At the same time, three decades of rapid economic growth have been accompanied by growing gaps between regions and social strata, resulting in social tensions that test the Party's governing ability. The government has responded to this social tension with its people-first policy and calls for building a harmonious society. While economic growth is clearly unable to automatically resolve social prob- lems, it remains to be seen whether the new people-first policy can be effectively implemented. There is a growing consensus among Chinese officials and scholars that the time has come to introduce substantive and major political reform. The decreasing executive capabilities of the party-state bureaucracy and especially local governments are manifested in widespread corruption and internal inertia. Placing them under public supervision has become more necessary than ever before.

After two decades of competitive elections carried out at the village and township levels, major decisions need to be made on the categories of elections and simplified procedures. Simply replicating the various previous experiments is inadvisable, given the excessive number of categories and methods of election and the complexity of their procedures. The achievements made to date can only be consolidated through the momentum of sustained development; without progress, there will be regression. As it is, the suspension of direct township elections in 2006 has manifested itself in the deteriorated quality of recently held village committee elections. In contrast to the recent past, Chinese media are reporting little on current village elections. In this sense, the re-introduction of competitive elections will not serve their purpose as a showcase unless they are granted greater room to manoeuvre.

One option worth considering is to organise the election of township Party and government leaders at the same time as People's Congress deputies. There are also many areas where the qualifications of candidates could be harmlessly reduced to, for example, those aged over 18, literate, and (if for the Party positions) being a Party member. Primary elections should be open to more voters, if not requiring the attendance of all voters. At least two kinds of "ticket systems" can be used: (1) the Party secretary and government head form a ticket; or (2) the government head selects deputy leaders. Candidates should be permitted to conduct campaigns supported by volunteers. Campaigning methods (such as funding and use of media) should be specified in campaign rules or regulations. Finally, the assembly of Party members and People's Congresses must respect the will of the voters and endorse the results of popular polls.

In short, more meaningful experiments require political decisions at the top. Sporadic piece-meal reform is unlikely to contribute significantly to democratisation.

36. Zhou Qiren, "Yibu wei wancheng de changquan gaige shi" (A history of unfinished ownership reform), Economic Observer News, 19 January 2009; He Zengke, "Jianjing zhengzhi gaige yu minzhu de zhengzhi zhuanxing" (Incremental political reform and democratic political transformation), 25 December 2008, http://www.china innovations.org/showNews.html?id=713. 